\title{
COMPARISON OF RESEARCH ENGAGEMENT OF PHD STUDENTS AT VARIOUS STUDY PROGRAMS AT CULS PRAGUE: AN INTRODUCTORY STUDY
}

\author{
Martin Flégl ${ }^{1}$, Hana Vostrá Vydrová ${ }^{2}$, Ivana Tichá ${ }^{2}$ \\ ${ }^{1}$ Business School, University La Salle, Mexico, ${ }^{2}$ Czech University of Life Sciences Prague
}

\author{
Highlights \\ - Doctoral study programs are assessed with research in focus. \\ - $\quad$ There is no significant difference in time allocated to research \\ - Form of study has impact on involvement in research projects \\ - $\quad$ PhD students at CULS Prague are dissatisfied with their research outputs
}

\section{Abstract}

Article type

In an attempt to improve the quality of doctoral studies and the satisfaction of $\mathrm{PhD}$ students at the Czech University of Life Sciences Prague (CULS Prague) the authors disseminated online questionnaire among all PhD students in May and June 2014. The questionnaire covered areas related to doctoral study, PhD supervisors, doctoral scholarship, research publications, and last but not least, to satisfaction with the doctoral study. In this article, responses related to research, such as allocation of time to doctoral studies, allocation of time to research, involvement in research projects and satisfaction with research outputs, are analyzed. The authors provide comparison of all above mentioned domains according to faculties as well as form of doctoral studies at CULS Prague.

\section{Keywords}

Doctoral studies, evaluation, PhD students, questionnaire, Pearson's test, Cramer's V

Flégl M. et al. (2014) "Comparison of Research Engagement of PhD Students at Various Study Programs at CULS Prague: An Introductory Study", Journal on Efficiency and Responsibility in Education and Science, Vol. 7, No. 3-4, pp. 66-73, online ISSN 1803-1617, printed ISSN 1803-1617, doi: 10.7160/eriesj.2014.070304.

\section{Introduction}

The higher education system in the Czech Republic is mainly financed from the budget of Ministry of Education, Youth and Sport (MEYS). The majority of Higher Education Institutions' (HEI) budgets depend on the institutional funding. This institutional funding is mainly influenced by the number of students (at all levels), types of study programs and indicators of quality and performance. Currently, this part covers approximately $80 \%$ from the whole MEYS budget (MEYS, 2014). Moreover, $22.5 \%$ out of these $80 \%$ are influenced by quality and performance indicators. Quality is, among others, influenced by HEIs' research results. In the Czech Republic, research results are measured based on a scheme developed by Research, Development and Innovation Council (RVVI, 2013).

Consequently, the importance of high profile research results has risen substantially. Moreover, due to a decrease of MEYS budget the competition for state funding in Czech higher educational system has increased. HEIs' performance has become an issue and comparative analyses have been recently published. For example, Vltavská and Fischer (2013) evaluated the labor productivity of HEIs' employees according to the teaching and research productivity. Furthermore, Flégl and Vltavská (2013) presented the efficiency analysis of the Faculties of Economics using Data Envelopment Analysis and production function analysis. Dlouhý (2012) proposed a model for funding allocation among HEI's departments based on publication productivity. Most recently, Jablonský (2014) presented a performance analysis of Czech scientists with respect to their publication activities. Jablonský also discussed the potential of bibliometric indicators as a tool for department, faculties or HEIs evaluations. In general, the authors use mathematical modeling for performance analysis in higher education, mainly benchmarking analysis. These benchmarking analyses use either nonparametric approaches based on Data envelopment analysis - DEA (Johnes, 2006; Korhonen, Tainio and Wallenius, 2001) or parametric approaches based on Stochastic Frontier Approach SFA (Furková, 2013; McMillan and Chan, 2006; Stevens, 2005)

As a result of increased competitions, many HEIs introduced internal stimulation schemes to enhance quality as well as quantity of research output of both $\mathrm{PhD}$ students and academic staff. In addition to the stimulation scheme the Faculty of Economics and Management (FEM), Czech University of Life Sciences Prague (CULS) launched Project for Innovation of the doctoral study program (IDSP) in March 2012 (Flégl, Tichá and Stanislavská Kvasničková, 2013) in order to deal with long term dissatisfaction of research performance. The project includes several parts (activities), such as Methodological workshops for PhD students and PhD supervisors. All project parts focus on improvement of research performance, mainly on $\mathrm{PhD}$ students and partly on $\mathrm{PhD}$ supervisors. PhD students at FEM have had lower level of research results in comparison with the other faculties at CULS Prague (Flégl, Tichá and Stanislavská Kvasničková, 2013).

The main cause of generally lower level of research results of FEM PhD students is related to inactivity of substantial proportion of PhD students. As Flegl and Vostra Vydrova (2014) pointed out a huge percentage of $\mathrm{PhD}$ students (in some cases more than 60\%) at CULS Prague had produced zero research results during the period 2007-2011. There is a number of various reasons behind low performance of $\mathrm{PhD}$ students. The influence of $\mathrm{PhD}$ supervisors on research results of $\mathrm{PhD}$ 
students is one of important reasons (Barnes and Austin, 2009). Pinheiro, Melkers and Youtie (2014) observed that coauthoring with the supervisor is a significant source of publications. Moreover, coauthoring and mentoring have positive impact for future research performance (Hilmer and Hilmer, 2009; Kyvik and Smeby, 1994). Besides the student-supervisor relationship, it is important to analyze other potential causes of lower level of research performance, such as allocation of time to doctoral studies or involvement in research projects.

The objective of the article is to provide an overview of $\mathrm{PhD}$ students' performance with regard to differences among faculties and form of studies (full-time and part-time). This overview includes areas related to a time allocation to doctoral studies, time spent on research, involvement in research projects and satisfaction with research outputs. Univariate and multivariate statistical analysis of categorical data is used to process data.

The next parts of the article are divided as follows: the following part specifies the analyzed data and describes statistical methods used for the data processing. The main part of the article focuses on the findings obtained through questionnaire and on the detailed description of responses. Discussion of findings and brief comments conclude the article.

\section{Materials and Methods}

\section{Data specification}

Czech University of Life Sciences Prague provided in total 18 doctoral study programs in $29 \mathrm{PhD}$ specializations at its faculties ${ }^{1}$ in the year 2014 (CULS, 2014). In these study programs, in total $1093 \mathrm{PhD}$ students were enrolled. In April 2014, the authors prepared online questionnaire for the evaluation of $\mathrm{PhD}$ studies at CULS. The questionnaire covers six main areas: questions related to students' introduction, questions related to doctoral study, questions related to PhD supervisor, questions related to doctoral scholarship, questions related to research publications, and questions related to satisfaction with the doctoral study. This article, however, focuses only on questions related to research activity. As several $\mathrm{PhD}$ study programs are taught in foreign language (mainly English) the questionnaire was prepared in both Czech and English version. The questionnaire contains of open-ended and closed questions, as well as a combination of both types. The main purpose of the questionnaire was to find out reasons of satisfactions and dissatisfactions with current doctoral studies at CULS Prague.

The questionnaire was disseminated among all $\mathrm{PhD}$ students in May and June 2014. The dissemination was supported by an official email sent to all $\mathrm{PhD}$ students. The authors also sent a reminder to this survey 2 weeks after the first dissemination. In total, $187 \mathrm{PhD}$ students (representing 17.11\%) have expressed their opinions about $\mathrm{PhD}$ studies at CULS Prague. Out of those 187 responses, $72 \mathrm{PhD}$ students were males and 115 were females (Table 1).

\begin{tabular}{lccc}
\hline \multirow{2}{*}{ Residency } & \multicolumn{3}{c}{ Gender } \\
\cline { 2 - 4 } & Male & Female & Total \\
Czech \& Slovak & 71 & 113 & 184 \\
residents & 1 & 2 & 3 \\
Foreign residents & 72 & 115 & 187 \\
Total & $38.50 \%$ & $61.50 \%$ \\
\hline Share & & \\
\hline
\end{tabular}

Table 1: Number of responses by gender and residency (source: own calculation)

In addition, the respondents can be divided into two basic groups according to their residency, i.e. Czech \& Slovak residents and foreigners. Only 3 responses from foreign $\mathrm{PhD}$ students were returned. From this reason, responses from foreign residents are excluded from the analysis. The majority of the $\mathrm{PhD}$ students (61.41\%) stated their permanent residence is in Prague and in Central Bohemia region (Table 2). This distribution is influenced by the location of CULS in Prague. PhD students with the permanent residence outside of the Czech Republic represent only $2.72 \%$ of respondents.

Table 3 summarizes the distribution of the respondents regarding their age. The majority of the PhD students are in the group 2630 years old $(72.28 \%)$. Considering that the majority of master students in the Czech Republic graduate around the age 26 and the length of doctoral studies at CULS Prague are 3 years in general, so this age distribution reflects well the conditions. Interesting finding is that $5.43 \%$ ( 10 out of 187 responses) of $\mathrm{PhD}$ students are older than 41 years old. Doctoral studies are not a matter only of a younger generation, but CULS Prague is also able to attract older students usually for part-time studies.

\begin{tabular}{lcr}
\hline \multicolumn{1}{c}{ Region } & $\begin{array}{c}\text { Czech \& Slovak } \\
\text { residents }\end{array}$ & Share \\
\hline City of Prague & 64 & $34.78 \%$ \\
Central Bohemia region & 49 & $26.63 \%$ \\
South Bohemian region & 7 & $3.80 \%$ \\
The Pilsen region & 4 & $2.17 \%$ \\
Karlovy Vary region & 3 & $1.63 \%$ \\
The Ústí region & 13 & $7.07 \%$ \\
Liberec region & 7 & $3.80 \%$ \\
Hradec Králové region & 7 & $3.80 \%$ \\
The Pardubice region & 7 & $3.80 \%$ \\
Vysočina region & 9 & $4.89 \%$ \\
Southern Moravia region & 2 & $1.09 \%$ \\
The Olomouc region & 1 & $0.54 \%$ \\
Moravian-Silesian region & 5 & $2.72 \%$ \\
Zlín region & 1 & $0.54 \%$ \\
outside the Czech Republic & 5 & $2.72 \%$ \\
Total & 184 & $100.00 \%$ \\
\hline
\end{tabular}

Table 2: Regions of permanent residence (source: own calculation) 


\begin{tabular}{ccr}
\hline Age groups & $\begin{array}{c}\text { Czech \& Slovak } \\
\text { residents }\end{array}$ & \multicolumn{1}{c}{ Share } \\
\hline $0-25$ & 14 & $7.61 \%$ \\
$26-30$ & 133 & $72.28 \%$ \\
$31-35$ & 20 & $10.87 \%$ \\
$36-40$ & 7 & $3.80 \%$ \\
41 and over & 10 & $5.43 \%$ \\
Total & 184 & $100.00 \%$ \\
\hline
\end{tabular}

Table 3: Age of the respondents (source: own calculation)

Most of the respondents (88.59\%) study full-time programs and only $11.41 \%$ of respondents are enrolled in part-time programs. Table 5 shows the distribution of received responses sorted by faculties at CULS Prague. The distribution corresponds with the size of the faculties, so the most responses are from FAFNR $(28.80 \%)$, FES $(23.37 \%)$ and FEM $(19.57 \%)$. Whereas the smallest faculty FTAS represents only $8.15 \%$ from all the responses.

\begin{tabular}{lccc}
\hline \multirow{2}{*}{ Residency } & \multicolumn{2}{c}{ Form of the study } & \\
& Full-time & Part-time & Total \\
\hline $\begin{array}{l}\text { Czech \& Slovak } \\
\text { residents }\end{array}$ & 163 & 21 & 184 \\
Share & $88.59 \%$ & $11.41 \%$ & $100.00 \%$ \\
\hline
\end{tabular}

Table 4: Form of the doctoral studies (source: own calculation)

\begin{tabular}{lcr}
\hline & $\begin{array}{c}\text { Number of } \\
\text { responses }\end{array}$ & \multicolumn{1}{c}{ Share } \\
\hline FAFNR & 53 & $28.80 \%$ \\
FFWS & 22 & $11.96 \%$ \\
FTAS & 15 & $8.15 \%$ \\
FES & 43 & $23.37 \%$ \\
FEM & 36 & $19.57 \%$ \\
FE & 15 & $8.15 \%$ \\
Total & 184 & $100.00 \%$ \\
\hline
\end{tabular}

Table 5: Number of responses according to faculty (source: own calculation)

\section{Statistics}

We use tools of univariate and multivariate statistical analysis of categorical data. The analysis of individual variable values is based on a frequency distribution and calculation of descriptive characteristics. The principles of dependencies of two variables are described on the basis of a contingency table. Chi-square test is chosen to test hypotheses about the independence of two variables. In case of a failure to comply with the basic test requirements, which is linked to the expected frequencies, we logically merge selected answers. Using the chi-square test we test the compliance of observed and expected frequencies. To calculate the test criterion we can use Person's chisquare statistics (Chambers and Skinner, 2003). In addition Cramer's V was applied to measure the strength of the proven dependencies.

The significance level $\alpha=0.05$ was set for testing statistical hypotheses. Statistical software SPSS 2.2 was used for a practical application of statistical tools.

\section{Results}

Following detailed description of achieved results is structured according to areas related to research of $\mathrm{PhD}$ students at CULS Prague (time allocated to doctoral studies, time allocated to research, involvement in research projects, research outputs and satisfaction with research outputs). In following subsections discussion and detailed explanation of achieved results is provided.

\section{How many hours per week PhD students spend at CULS Prague as a part of their doctoral studies?}

This subsection focuses on the amount of time $\mathrm{PhD}$ students spend at faculty as a part of their doctoral studies. This analyzes tries to find out differences either between faculties of CULS Prague or between different form of studies (full-time and parttime studies). Therefore, the following hypothesis is tested:

$H_{0}$ : There is no statistically significant dependence between number of hours PhD students spend at a faculty and the faculty.

Table 6 summarizes both numbers of hours per faculty and calculated statistical characteristics. As a result, $H_{0}$ is rejected $(p=0.0000)$, so there is a statistically significant dependence between PhD students and number of hours they spend at a faculty as a part of their doctoral studies. A significant difference between PhD students from FAFNR and the rest of the university, regarding the time they spend at faculty, can be observed from Table 6. Most of the PhD students (57.4\%) at FAFNR spend 30 and more hours at the faculty per week. This is significantly much more compared to the other faculties, where the average is only around 9.73 hours. On the other hand, 55.81\% of $\mathrm{PhD}$ students from FES spend mostly between 0 to 9 hours at the faculty as a part of their doctoral studies. Similar results can be observed for PhD students from FFWS. In addition, Cramer's V implies to a moderately strong dependence (0.3199).

\begin{tabular}{lcccccll}
\hline & \multicolumn{5}{c}{ Number of hours } & & \multicolumn{2}{l}{ Statistics } \\
\cline { 2 - 6 } Faculty & $0-9$ & $10-19$ & $20-29$ & $30-39$ & $\begin{array}{c}40 \text { and } \\
\text { more }\end{array}$ & & \\
\hline FAFNR & 9 & 4 & 9 & 13 & 18 & Pearson's test & 75.3314 \\
FFWS & 11 & 5 & 4 & 0 & 2 & p-value & 0.0000 \\
FTAS & 4 & 3 & 3 & 5 & 0 & Cramer's V & 0.3199 \\
FES & 24 & 7 & 9 & 2 & 1 & & \\
FEM & 9 & 15 & 8 & 3 & 1 & & \\
FE & 1 & 4 & 6 & 2 & 2 & & \\
Total & 58 & 38 & 39 & 25 & 24 & & \\
\hline
\end{tabular}

Table 6: Number of hours PhD students spend at faculty according to faculty (source: own calculation)

As the second part of this area, following hypothesis is tested:

$H_{0}$ : There is no statistically significant dependence between $\mathrm{PhD}$ students of the full-time and part-time form of study according to number of hours they spend at a faculty.

Table 7 summarizes numbers of hours PhD students of fulltime and part-time form of study spend at a faculty as a part of their doctoral studies. Logically, students of full-time form of study spend significantly more hours at their faculties (this is an expected result). Considering the calculated statistical characteristics, $H_{0}$ is rejected $(p=0.0011)$, so there is a statistically significant dependence between $\mathrm{PhD}$ students of different form of study and number of hours they spend at a faculty. Moreover, Cramer's V implies to a moderately strong dependence (0.3154). 


\begin{tabular}{|c|c|c|c|c|c|c|c|}
\hline \multirow{2}{*}{$\begin{array}{c}\text { Type of } \\
\text { study }\end{array}$} & \multicolumn{5}{|c|}{ Number of hours } & \multirow{2}{*}{\multicolumn{2}{|c|}{ Statistics }} \\
\hline & $0-9$ & $10-19$ & $20-29$ & $30-39$ & $\begin{array}{c}40 \text { and } \\
\text { more }\end{array}$ & & \\
\hline Full-time & 43 & 36 & 37 & 23 & 24 & $\begin{array}{l}\text { Pearson's } \\
\text { test }\end{array}$ & 18.3018 \\
\hline Part-time & 15 & 2 & 2 & 2 & 0 & p-value & 0.0011 \\
\hline Total & 58 & 38 & 39 & 25 & 24 & Cramer's V & 0.3154 \\
\hline
\end{tabular}

Table 7: Number of hours PhD students spend at faculty according to form of study (source: own calculation)

Do PhD students allocate all their working time to their doctoral studies only?

This following subsection tries to find out the proportion of working time allocated to doctoral studies and to work elsewhere (outside a department). Firstly, the differences in responses between faculties of CULS Prague are analyzed. The following hypothesis is tested:

$H_{0}$ : There is no statistically significant dependence between PhD students' time allocated to studies and faculties.

In this case, $\mathrm{PhD}$ students could answer simply either yes or no. Table 8 summarizes responses from $\mathrm{PhD}$ students according to their faculties. In addition, calculated statistical characteristics are also included. $H_{0}$ is rejected $(p=0.0034)$, because there is a statistically significant dependence between time allocated to doctoral studies and faculties. Majority of respondents divide their time between doctoral studies and a work outside their department. As in the previous subsection, $\mathrm{PhD}$ students at FAFNR represent difference as they allocate their time more often to doctoral studies only. This result is in alignment with the numbers of hours these PhD students spend at their faculty (Table 6).

On the other side, it can be observed that almost all respondents from FE (except one $\mathrm{PhD}$ student representing 7.14\% from all respondents from FE) devote their time also to other work outside their department. Similarly, only $22.22 \% \mathrm{PhD}$ students from FFWS, 22.85\% PhD students from FES and 24.14\% $\mathrm{PhD}$ students from FEM allocate their time only to their doctoral studies. It represents approximately each $4^{\text {th }}$ or $5^{\text {th }} \mathrm{PhD}$ student focuses only on the doctoral study. Similarly as for the previous testing, Cramer's V implies to a moderately strong dependence (0.3099).

\begin{tabular}{lcclc}
\hline Faculty & Yes & No & \multicolumn{1}{c}{ Statistics } & \\
\hline FAFNR & 25 & 28 & Pearson's test & 17.6759 \\
FFWS & 4 & 18 & p-value & 0.0034 \\
FTAS & 4 & 11 & Cramer's V & 0.3099 \\
FES & 8 & 35 & & \\
FEM & 7 & 29 & & \\
FE & 1 & 14 & & \\
$\quad$ Total & 49 & 135 & & \\
\hline
\end{tabular}

Table 8: Devotion of working time only to doctoral studies according to faculty (source: own calculation)

$H_{0}$ : There is no statistically significant dependence between PhD students of the full-time and part-time form of study and time allocated to doctoral studies.

Table 9 summarizes responses and calculated statistical characteristics according to form of study and time allocated to doctoral studies. As expected, $H_{0}$ is rejected $(p=0.0160)$, so there is a statistically significant dependence between form of study and time allocated to doctoral studies. All PhD students from part-time study forms are supposed to work outside their departments. The one PhD students of part-time study form who stated an allocation of time fully to doctoral studies can represent maternity leave. This, however, cannot be verified from received responses. Cramer's V implies weak dependence (0.1748) among responses.

\begin{tabular}{cccll}
\hline $\begin{array}{c}\text { Type of } \\
\text { study }\end{array}$ & Yes & No & \multicolumn{1}{c}{ Statistics } & \\
\hline Full-time & 48 & 115 & Pearson's test & 5.8022 \\
Part-time & 1 & 20 & p-value & 0.0160 \\
Total & 49 & 135 & Cramer's V & 0.1748 \\
\hline
\end{tabular}

Table 9: Devotion of working time only to doctoral studies according to form of study (source: own calculation)

\section{Approximately how many hours per week PhD students spend with their doctoral research?}

$H_{0}$ : There is no statistically significant dependence between number of hours PhD students allocate to research and the faculty.

Students' responses and calculated statistical characteristics are summarized in Table 10. In this case and contrary to the previous results, $H_{0}$ is not rejected ( $p=0.0844$ ), as there is no statistically significant dependence between time allocated to research and faculties to which $\mathrm{PhD}$ students belong. Moreover, Cramer's V implies to a weak dependence among responses (0.1991). At all faculties, $\mathrm{PhD}$ student allocate, in most of the cases, approximately $10-19$ hours per week to their research. FAFNR is not an exception this time and $\mathrm{PhD}$ students from this faculty allocate similar proportion of their time to research as, for example, PhD students from FES.

Considering the previous testing (total number of hours spent at faculty in Table 6) many $\mathrm{PhD}$ students from FAFNR spend almost half of their time with other activities then research (teaching, administrative work, etc.). This comment is based on the huge changes in time categories comparing Table 6 and Table 10.

Responses of $\mathrm{PhD}$ students from FEM indicate that they allocate most of their time to research (there are no significant changes in time categories comparing Table 6 and Table 10). Small inconsistency in responses from $\mathrm{PhD}$ students from FES can be observed. In Table 6 there are $24 \mathrm{PhD}$ students that spend approximately $0-9$ hours per week as a part of their doctoral studies. However, only $11 \mathrm{PhD}$ students allocate $0-9$ hours to research (Table 10). These PhD students either miscalculated their time allocation or they allocate to research some time beyond their doctoral studies. Few similar inconsistencies in responses from the other faculties can also be observed.

\begin{tabular}{lccccclll}
\hline & \multicolumn{5}{c}{ Number of hours } & & \multicolumn{2}{l}{ Statistics } \\
\cline { 2 - 6 } Faculty & $0-9$ & $10-19$ & $20-29$ & $30-39$ & $\begin{array}{c}40 \text { and } \\
\text { more }\end{array}$ & & \\
\hline FAFNR & 7 & 18 & 15 & 8 & 5 & $\begin{array}{l}\text { Pearson's } \\
\text { test }\end{array}$ & 29.1739 \\
FFWS & 8 & 8 & 4 & 2 & 0 & p-value & 0.0844 \\
FTAS & 4 & 4 & 7 & 0 & 0 & Cramer's V & 0.1991 \\
FES & 11 & 15 & 10 & 6 & 1 & & \\
FEM & 13 & 16 & 5 & 2 & 0 & & \\
FE & 3 & 9 & 2 & 0 & 1 & & \\
Total & 46 & 70 & 43 & 18 & 7 & & \\
\hline
\end{tabular}

Table 10: Number of hours allocated to research by PhD students according to faculty (source: own calculation) 
$H_{0}$ : There is no statistically significant dependence between PhD students of full-time and part-time form of study and time allocated to research.

Table 11 summarizes numbers of hours $\mathrm{PhD}$ students of both full-time and part-time forms of study allocate to their research as a part of their doctoral studies. Considering the calculated statistical characteristics, $H_{0}$ is not rejected $(p=0.0751)$, so there is no statistically significant dependence between form of study and number of hours allocated to research. Possible explanation is that, even though $\mathrm{PhD}$ students in part-time programs spend significantly less hours at a faculty (Table 7), it is due to a lower teaching involvement. Research is not affected and students in both forms of studies allocate approximately the same amount of time to research.

\begin{tabular}{|c|c|c|c|c|c|c|c|}
\hline \multirow{2}{*}{$\begin{array}{l}\text { Type of } \\
\text { study }\end{array}$} & \multicolumn{5}{|c|}{ Number of hours } & \multirow{2}{*}{\multicolumn{2}{|c|}{ Statistics }} \\
\hline & $0-9$ & $10-19$ & $20-29$ & $30-39$ & $\begin{array}{c}40 \text { and } \\
\text { more }\end{array}$ & & \\
\hline Full-time & 36 & 65 & 38 & 18 & 6 & $\begin{array}{l}\text { Pearson's } \\
\text { test }\end{array}$ & 8.4919 \\
\hline Part-time & 10 & 5 & 5 & 0 & 1 & $\mathrm{p}$-value & 0.0751 \\
\hline Total & 46 & 70 & 43 & 18 & 7 & Cramer's V & 0.2148 \\
\hline
\end{tabular}

Table 11: Number of hours allocated to research by PhD students according to form of study (source: own calculation)

\section{Are $\mathrm{PhD}$ students involved as principal researchers in research projects?}

Following two subsections analyze involvement of $\mathrm{PhD}$ students in research projects. The questionnaire includes questions related to different types of research projects, such as: university internal grant agency (IGA); university-wide internal agency (CIGA); external projects (such as ESF funds); and external research projects (such as Czech Science Foundation GACR). However, due to a not sufficient amount of responses, following analysis considers involvement of PhD students only as a principal or associate researcher in general. This subsection focuses on principal researcher. Therefore, the following hypothesis is tested:

$H_{0}$ : There is no statistically significant dependence between involvement of PhD students as principal researchers in research projects and the faculty.

Table 12 summarizes responses from $\mathrm{PhD}$ students and statistical characteristics. In this case, $H_{0}$ is rejected $(p=0.0145)$, because there is a statistically significant dependence between responses and particular faculty. Cramer's V implies to a weak dependence (0.2777). As a result significant differences between faculties can be observed. For example, a majority of $\mathrm{PhD}$ students at FES $(69.77 \%)$ and FE (66.67\%) responded that they are involved in research projects as principal researchers. In addition, $50 \%$ of $\mathrm{PhD}$ students at FFWS declared their involvement as principal researchers in research projects. On the other side, at FTAS only $20 \% \mathrm{PhD}$ students are involved in research projects as principal researchers. Lower number of principal researchers at FTAS can be related to a lower allocation of time only to doctoral studies (Table 8) and vice versa.

\begin{tabular}{lccll}
\hline \multicolumn{1}{c}{ Faculty } & Yes & No & \multicolumn{1}{c}{ Statistics } & \\
\hline FAFNR & 24 & 29 & Pearson's test & 14.1898 \\
FFWS & 11 & 11 & p-value & 0.0145 \\
FTAS & 3 & 12 & Cramer's V & 0.2777 \\
FES & 30 & 13 & & \\
FEM & 17 & 19 & & \\
FE & 10 & 5 & & \\
\multicolumn{1}{c}{ Total } & 95 & 89 & & \\
\hline
\end{tabular}

Table 12: Involvement in research projects as principal researcher according to faculty (source: own calculation)

$H_{0}$ : There is no statistically significant dependence between PhD students of full-time and part-time form of study and involvement as principal researchers in research projects.

Similar result is obtained when involvement in research projects is analyzed comparing different form of studies. Again $H_{0}$ is rejected ( $p=0.0067)$, so there is a statistically significant dependence between responses and form of study (Table 13). As expected, $\mathrm{PhD}$ students from full-time form of study are mainly involved as principal researchers $(55.21 \%)$, whereas part-time $\mathrm{PhD}$ students are involved only in $23.81 \%$ of cases. Managing research projects require nearly full-time involvement, so fulltime form of study is more appropriate. Cramer's V implies weak dependence $(0.1960)$ among responses.

\begin{tabular}{lccll}
\hline \multicolumn{1}{c}{ Type of study } & Yes & No & \multicolumn{1}{c}{ Statistics } & \\
\hline Full-time & 90 & 73 & Pearson's test & 7.3471 \\
Part-time & 5 & 16 & p-value & 0.0067 \\
$\quad$ Total & 95 & 89 & Cramer's V & 0.1960 \\
\hline
\end{tabular}

Table 13: Involvement in research projects as principal researcher according to type of study (source: own calculation)

\section{Are $\mathrm{PhD}$ students involved as associate researchers in research projects?}

Similarly, PhD students' involvement in research projects in the role of associate researchers can be analyzed. Following hypothesis is tested:

$H_{0}$ : There is no statistically significant dependence between involvement of PhD students as associate researchers in research projects and the faculty.

Table 14 summarizes responses from $\mathrm{PhD}$ students and statistical characteristics. In this case, and contrary to the previous subsection, $H_{0}$ is not rejected $(p=0.4108)$, and there is no statistically significant dependence between responses and particular faculty. Therefore, most of the $\mathrm{PhD}$ students from all faculties are involved in research projects as associate researchers. In almost all the cases more than $50 \%$ of $\mathrm{PhD}$ students stated their involvement as associate researches.

\begin{tabular}{lccll}
\hline Faculty & Yes & No & \multicolumn{1}{c}{ Statistics } & \\
\hline FAFNR & 30 & 23 & Pearson's test & 5.0421 \\
FFWS & 13 & 9 & p-value & 0.4108 \\
FTAS & 10 & 5 & Cramer's V & 0.1655 \\
FES & 21 & 22 & & \\
FEM & 20 & 16 & & \\
FE & 12 & 3 & & \\
\multicolumn{1}{c}{ Total } & 106 & 78 & & \\
\hline
\end{tabular}

Table 14: Involvement in research projects as associate researcher according to faculty (source: own calculation) 
$H_{0}$ : There is no statistically significant dependence between PhD students of full-time and part-time form of study and involvement as associate researchers in research projects.

Analysis of involvement in research projects as associate researcher comparing different form of studies, allows rejecting $H_{0}(p=0.042)$, thus there is a statistically significant dependence between responses and form of study (Table 15). PhD students from full-time form of study are mainly involved as associate researchers (61.34\%) in research projects. On the other hand, $\mathrm{PhD}$ students from part-time form of study are involved only in $28.57 \%$ of cases. Involvement of part-time PhD students does not depend on a position in research projects. Involvement of these $\mathrm{PhD}$ students is low in both cases, i.e. as principal and associate researchers. Cramer's V implies weak dependence (0.2064) among responses.

\begin{tabular}{cccll}
$\begin{array}{c}\text { Type of } \\
\text { study }\end{array}$ & Yes & No & \multicolumn{1}{c}{ Statistics } & \\
\hline Full-time & 100 & 63 & Pearson's test & 8.1846 \\
Part-time & 6 & 15 & p-value & 0.0042 \\
Total & 106 & 78 & Cramer's V & 0.2064 \\
\hline
\end{tabular}

Table 15: Involvement in research projects as associate researcher according to form of study (source: own calculation)

\section{How many research outputs $\mathrm{PhD}$ students publish?}

The last part of the analysis is related to research outputs published by $\mathrm{PhD}$ students at their faculties. The authors compare research outputs according to the official RIV categories (RVVI, 2013) ${ }^{2}$. In addition, the authors decided to compare only categories of research outputs and not number of research outputs due to a different number of responses between faculties. However, this analysis can still provide sufficient information about research orientation at particular faculty. Following hypothesis is tested:

$H_{0}$ : There is no statistically significant dependence between categories of research outputs and faculties.

Table 16 summarizes both numbers of research outputs sorted by categories and calculated statistical characteristics. As a result, $H_{0}$ is rejected $(p=0.0380)$, thus there is a statistically significant dependence between research output categories and faculties. Differences can be observed between FAFNR, FFWS, FTAS, FES and the rest of CULS Prague, whose PhD students have a lot of research outputs in Jimp and Jneimp categories. More precisely, PhD students at FAFNR publish in Jimp category in $22.73 \%$ of cases, at FFWS $(31.43 \%)$, FTAS $(22.22 \%)$, and FES (20.29\%). On the other hand, PhD students at FEM and FE publish fewer outputs in Jimp category (FEM only 5.8\% and FE $8.11 \%$ ), and publish more in Jneimp, Jrec and D category. Comparison of distribution of research outputs as a whole for CULS Prague reveals, that the distribution is equal between all categories (except proceeding category). Cramer's V implies to a moderately strong dependence $(0.3020)$.

Article published in a periodical in the Web of Science (Jimp), article published in a periodical registered either in SCOPUS or ERIH (Jneimp), article in a reviewed Czech periodical, which is not registered in WoS, SCOPUS, or ERIH (Jrec), article in proceedings registered in Thomson Reuters (D), and article in proceedings not registered in Thomson Reuters (proceeding).

\begin{tabular}{lccccclll}
\hline \multirow{2}{*}{ Faculty } & \multicolumn{3}{c}{ Categories of research outputs } & & \multirow{2}{*}{ Statistics } \\
\cline { 2 - 6 } & Jimp & Jneimp & Jrec & D & proceeding & & \\
\hline FAFNR & 20 & 11 & 17 & 10 & 30 & $\begin{array}{l}\text { Pearson's } \\
\text { test }\end{array}$ & 32.5050 \\
FFWS & 11 & 9 & 2 & 1 & 12 & p-value & 0.0380 \\
FTAS & 6 & 3 & 2 & 6 & 10 & Cramer's & 0.3020 \\
FES & 14 & 12 & 14 & 6 & 23 & & \\
FEM & 4 & 12 & 14 & 13 & 26 & & \\
FE & 3 & 10 & 7 & 7 & 10 & & \\
Total & 58 & 57 & 56 & 43 & 111 & & \\
\hline
\end{tabular}

Table 16: Categories of research outputs according to faculty (source: own calculation)

Difference in research outputs categories regarding form of study is also tested based on following hypothesis:

$H_{0}$ : There is no statistically significant dependence between categories of research outputs and form of study.

Contrary to the previous result, $H_{0}$ is not rejected $(p=0.7180)$, thus there is no statistically significant dependence between research output categories and form of study (Table 17). So even though PhD students of part-time form of study spend significantly less time at faculty (Table 7) and they are less involved in research projects (Table 13 and Table 15), there is no statistically significant difference in research output categories. Different results, however, provides an analysis of total number of publications.

\begin{tabular}{cccccclll}
\hline \multirow{2}{*}{$\begin{array}{c}\text { Type of } \\
\text { study }\end{array}$} & \multicolumn{3}{c}{ Categories of research outputs } & & \multicolumn{2}{c}{ Statistics } \\
\cline { 2 - 6 } & \multicolumn{3}{c}{ Jimp } & Jneimp Jrec & D & proceeding & & \\
\hline Full-time & 50 & 51 & 48 & 35 & 99 & & Pearson's test & 2.0960 \\
Part-time & 8 & 6 & 8 & 8 & 12 & & p-value & 0.7180 \\
Total & 58 & 57 & 56 & 43 & 111 & Cramer's V & 0.0800 \\
\hline
\end{tabular}

Table 17: Categories of research outputs according to form of study (source: own calculation)

\section{Are PhD students satisfied with the number and categories of their published research outputs?}

The last subsection of the results is focused on the level of satisfaction of $\mathrm{PhD}$ students with their research outputs. The questionnaire contained of following possible answers; definitely not, not very, I do not know, quite satisfied, and completely satisfied. The authors decided to merge categories (to satisfied, not satisfied, and I do not know) due to fewer number of responses. Moreover, "I do not know" category was eliminated from the statistical analyses, because in total only 11 responses were obtained and zero responses at FFWS and FE (Table 18). Finally, following hypothesis is tested:

$H_{0}$ : There is no statistically significant dependence between satisfaction with research outputs and faculties.

Table 18 summarizes calculated statistical characteristics. As a result, $H_{0}$ is not rejected ( $\left.p=0.5548\right)$, thus there is no statistically significant dependence between satisfaction with research output and faculties. Surprisingly, most of the PhD students across the faculties are not satisfied with their research outputs (neither categories nor number of published outputs). The average dissatisfaction at CULS Prague reaches a level of 70\%! Students at FE represent an exception, when their dissatisfaction is only $53.33 \%$. If responses from FE are excluded, then the dissatisfaction average increases up to $74 \%$. 
The reason of high dissatisfaction at FEM can be explained with a low number of research outputs in Jimp category (Table 16). That is in contrary to PhD students from FE who have even fewer Jimp outputs than FEM. However, PhD students at FE are the most satisfied from CULS Prague. Dissatisfaction of $\mathrm{PhD}$ students at FAFNR, FFWS, FTAS and FES is quite surprising regarding number of research outputs in Jimp and Jneimp categories. However, dissatisfaction with published research outputs can lie somewhere else. We only make assumption according to the analyzed results in this article. Therefore, further analysis is necessary for finding complex reasons.

\begin{tabular}{lcccll}
\hline Faculty & Satisfied & $\begin{array}{c}\text { Not } \\
\text { satisfied }\end{array}$ & $\begin{array}{c}\text { Do not } \\
\text { know }\end{array}$ & \multicolumn{1}{c}{ Statistics } & \\
\hline FAFNR & 16 & 33 & 4 & Pearson's test & 3.9628 \\
FFWS & 4 & 11 & 0 & p-value & 0.5548 \\
FTAS & 11 & 29 & 3 & Cramer's V & 0.1513 \\
FES & 4 & 16 & 2 & & \\
FEM & 8 & 26 & 2 & & \\
FE & 7 & 8 & 0 & & \\
$\quad$ Total & 50 & 123 & 11 & & \\
\hline
\end{tabular}

Table 18: Satisfaction of PhD students with their research outputs according to faculty (source: own calculation)

Differences in satisfaction regarding form of study are tested with following hypothesis:

$H_{0}$ : There is no statistically significant dependence between satisfaction with research outputs and form of study.

In this case, $H_{0}$ is not rejected ( $p=0.6327$ ), so there is no statistically significant dependence between satisfaction with research output and form of study. Dissatisfaction of full-time $\mathrm{PhD}$ students is $71.7 \%$, while part-time $\mathrm{PhD}$ students reach $66.7 \%$. In both cases the results correspond with average dissatisfaction between faculties.

\begin{tabular}{lccclc}
\hline Faculty & Yes & No & Do not know & \multicolumn{1}{c}{ Statistics } & \\
\hline Full-time & 43 & 109 & 11 & Pearson's test & 0.2284 \\
Part-time & 7 & 14 & 0 & p-value & 0.6327 \\
Total & 50 & 123 & 11 & Cramer's V & - \\
\hline
\end{tabular}

Table 19: Satisfaction of $P h D$ students with their research outputs according to form of study (source: own calculation)

\section{Discussion}

Responses from $\mathrm{PhD}$ students show significant differences in many areas. First of all, the form of study has significant impact on research results of $\mathrm{PhD}$ students. Students of parttime form of study spend significantly less time at a faculty. These students divide their time between the time at a faculty and the time outside the faculty. However, the time outside a faculty does not influence the proportion of time allocated to research. $\mathrm{PhD}$ students of both full-time and part-time forms spend approximately the same amount of time with research. Therefore, the difference in time allocation to a faculty is most likely linked to other duties at a department. Full-time $\mathrm{PhD}$ students probably teach more classes per week and $\mathrm{PhD}$ students of part-time form of study are primarily hired for research.

On the other hand, part-time form of study negatively affects involvement in research projects. Therefore, if CULS Prague is to improve its research results, full-time $\mathrm{PhD}$ students should be in focus. It is, however, not enough. There should be a tighter connection between supervisor and $\mathrm{PhD}$ student. As Barnes and Austin (2009) pointed out, the influence of $\mathrm{PhD}$ supervisors plays important role in research results of $\mathrm{PhD}$ students. In addition, Pinheiro, Melkers and Youtie (2014) observed that co-authoring with a supervisor is a significant source of publications. Moreover, this co-authoring and mentoring have positive impacts for future research performance. Therefore, proper supervising could lead to diminishing zero research results of PhD students, as Flegl and Vostra Vydrova (2014) observed.

This improvement must go along with a proper $\mathrm{PhD}$ students' education. As Lee and Kamler (2008) pointed out, learning how to write and speak in discipline-specific way, how to frame research questions, and how to effectively collaborate are important in science fields. This learning should be provided on a faculty or department basis. This requires $\mathrm{PhD}$ students willing to take research-related courses. This can be facilitated by learners-friendly environment at department as well as faculty level.

Secondly, the authors observed significant differences among faculties in many aspects. Obviously, each faculty requires different workload. PhD students at FAFNR spend significantly more time at the faculty ( 30 and more hours). Moreover, $\mathrm{PhD}$ students at FAFNR publish a lot of articles in Jimp and Jneimp categories (similarly as $\mathrm{PhD}$ students at FES). This result corresponds with the findings of Flégl, Tichá and Stanislavská Kvasničková (2013). In their study, four PhD specializations from FAFNR and FES reached the highest research performance among all $\mathrm{PhD}$ specializations at CULS Prague. This implies the close link between time spent at faculty and research performance.

The last but not least, $\mathrm{PhD}$ students at some faculties allocate their time mostly to research. For example, some PhD students at FEM expressed their time allocation to doctoral studies at the same level as time allocation to research. So why FEM does not reach the same level of research outputs as FAFNR or FES? Firstly, there might be possible influence of hardly comparable research fields (social sciences versus natural sciences). Secondly, different teaching workload might also affect the level of research performance. And finally, low level of the students' research experience ${ }^{3}$. More in depth analysis confirming causes of differences is needed in order to design and implement schemes enhancing the level of research performance.

\section{Conclusion}

The authors provide analysis of research activity at CULS Prague with focus on doctoral studies. The analysis is a response to an increasing pressure for higher profile research results. The analysis covers areas related to a time allocation to doctoral studies, time allocated to research, involvement in research projects and satisfaction with research outputs. All these areas are analyzed with regard to differences among faculties and forms of doctoral studies at CULS Prague.

The authors found many differences among faculties. For example, $57.4 \%$ of PhD students at FAFNR spend significantly more time (30 and more hours) at their faculty in comparison with the other PhD students. The average at CULS Prague is only around 10 hours. In addition, PhD students at FAFNR allocate their time more often to only doctoral studies. Therefore, $\mathrm{PhD}$ students from other faculties divide more often their time between doctoral studies and other activities outside their faculties. On the other side, any significant differences between

\footnotetext{
Other reasons should be taken in an account, such as low scholarship, department's environment etc. But the influence of these factors is not the main objective of this article.
} 
time allocations to research were found. At all faculties, $\mathrm{PhD}$ students allocate approximately 10 - 19 hours per week to their research.

In most of the cases, significant differences between full-time and part-time $\mathrm{PhD}$ students were found. For example, parttime $\mathrm{PhD}$ students spend significantly less time at their faculty. Furthermore, these $\mathrm{PhD}$ students do not allocate their time only to doctoral studies. Part-time form of study negatively influences involvement in research projects. This negative influence has an impact in both types of involvement, i.e. as a principal and as an associate researcher. Form of study does not have a direct impact on categories of research outputs. Thus, both full-time and part-time $\mathrm{PhD}$ students publish similar categories. This analysis did not cover the issue of amount of published results.

The last significant area of this analysis is related to a satisfaction with research outputs. Even though differences can be observed among faculties and form of studies in other analyzed areas, all $\mathrm{PhD}$ students are dissatisfied with their research results. The average dissatisfaction at CULS Prague reaches a level of $70 \%$ ! Students at FE expressed the lowest level of dissatisfaction $(53.33 \%)$. Moreover, this dissatisfaction was expressed by fulltime and part-time $\mathrm{PhD}$ students similarly.

The disseminated questionnaire covers more areas, but not all could be included in this analysis. Therefore, the future research will analyze other areas such as cooperation with $\mathrm{PhD}$ supervisors, satisfaction with doctoral studies or the issue of appropriate remuneration of $\mathrm{PhD}$ students. The authors would like to find out the reasons of most of the dissatisfactions. Moreover, the authors would also like to find out the reasons behind better research results of $\mathrm{PhD}$ students at some faculties.

\section{References}

Barnes, B. J. and Austin, A. E. (2009) 'The role of doctoral advisors: A look at advising from the advisor's perspective', Innovative Higher Education, vol. 33, no. 5, pp. 297-315. http:// dx.doi.org/10.1007/s10755-008-9084-X.

Chambers, R. L. and Skinner, C. J. (2003) Analysis of survey data, Wiley http://dx.doi.org/10.1002/0470867205

CULS (2014) Science \& Research-Doctoral studies, [online], Available: http://www.czu.cz/en/?r=6142, [1 Dec 2014].

Dlouhý, M. (2012) 'Efficiency and resource allocation within a hierarchical organization', Proceedings of 30th International Conference Mathematical Methods in Economics, Karviná: School of Business Administration, Silesian University, pp. 112116.

Flégl, M., Tichá, I. and Stanislavská Kvasničková, L. (2013) 'Innovation of doctoral studies at the FEM CULS Prague', Journal on Efficiency and Responsibility in Education and Science, vol. 6, no. 4, pp. 265-280. http://dx.doi.org/10.7160/ eriesj.2013.060405

Flégl, M. and Vltavská, K. (2013) 'Efficiency at Faculties of Economics in the Czech Public Higher Education Institutions: Two Different Approaches', International Education Studies, vol. 6, no. 10, pp. 1-12. http://dx.doi.org/10.5539/ies.v6n10p1

Flegl, M. and Vostra Vydrova, H. (2014) 'Is Pareto's 80-20 rule applicable in research? A case of CULS Prague', Proceedings of 11th International Conference on Efficiency and Responsibility in Education (Erie 2014), Prague: Faculty of Economics and Management, Czech University of Life Sciences Prague, pp. 125-131.
Furková, A. (2013) 'Alternative approaches to efficiency evaluation of higher eduation institutions', Journal on Efficiency and Responsibility in Education and Science, vol. 6, no. 3, pp. 167-178. http://dx.doi.org/10.7160/eriesj.2013.060304

Hilmer, M. J. and Hilmer, Ch. E. (2009) 'Fishes, ponds, and productivity: Student-advisor matching and early career publishing success for economics PhDs', Economic Inquiry, vol. 47, no. 2, pp. 290-303. http://dx.doi.org/10.1111/j.14657295.2007.00108.x

Jablonský, J. (2014) 'Bibliometric indicators and their comparison on the set of Czech scientists', Proceedings of 11th International Conference on Efficiency and Responsibility in Education (Erie 2014), Prague: Faculty of Economics and Management, Czech University of Life Sciences Prague, pp. 255-261.

Johnes, J. (2006) 'Data envelopment analysis and its application to the measurement of efficiency in higher education', Economics of Education Review, vol. 25, pp. 273-288. http:// dx.doi.org/10.1016/j.econedurev.2005.02.005

Korhonen, P., Tainio, R. and Wallenius, J. (2001) 'Value efficiency analysis of academic research', European Journal of Operational Research, vol. 130, no. 1, pp. 121-132. http:// dx.doi.org/10.1016/S0377-2217(00)00050-3

Kyvik, S. and Smeby, J.-Ch. (1994) 'Teaching and research. The relationship between the supervision of graduate students and faculty research performance', Higher Education, vol. 28, no. 2, pp. 227-239.

McMillan, M. L. and Chan, W. H. (2006) 'University efficiency: a comparison and consolidation of results from stochastic and non-stochastic methods', Education Economics, vol. 14, no. 1, pp. 1-30. http://dx.doi.org/10.1080/09645290500481857

MEYS (2014) Rozpis rozpočtu vysokých škol na rok 2014 (in Czech, Schedule of funding for higher education institutions for the year 2014), [online], Available: http://www.msmt.cz/ vzdelavani/vysoke-skolstvi/rozpis-rozpoctu-vysokych-skol-narok-2014 [28 Nov 2014].

Pinheiro, D., Melkers, J. and Youtie, J. (2014) 'Learning to play the game: Student publishing as an indicator of future scholarly success', Technological Forecasting and Social Change, vol. 81, pp. 56-66. http://dx.doi.org/10.1016/j.techfore.2012.09.008

RVVI (2013) Methodology of Evaluation of Research Organizations and Evaluation of Finished Programmes (valid for years 2013 - 2015), [online], Available: http://www.vyzkum. cz/FrontClanek.aspx?idsekce=695512 [25 Nov 2014].

Stevens, P. A. (2005) 'A stochastic frontier analysis of English and Welsh universities', Education Economics, vol. 13, no. 4, pp. 355-374. http://dx.doi.org/10.1080/09645290500251581

Vltavská, K. and Fischer, J. (2013) 'Is It Possible to Estimate Labour Productivity in the Czech Higher Education?', Journal on Efficiency and Responsibility in Education and Science, vol. 6, no. 1, pp. 34-45. http://dx.doi.org/10.7160/eriesj.2013.060104 